\title{
ADATTÁR
}

MIKÓ ÁRPÁD

\section{AZ EGYETEMI KÖNYVTÁR DANTE-KÓDEXÉNEK (COD. ITAL. 1.) EREDETI KÖTÉSÉRŐL}

\author{
HENSZLMANN IMRE KIADATLAN FELJEGYZÉSE
}

Az Egyetemi Könyvtár 14. századi Dante-kódexe (Cod. Ital. 1.) eminens darabja a Magyarországon őrzött középkori kéziratállománynak. Sokat foglalkoztak vele idehaza, és nagy értékét jelzi, hogy 2006-ban Veronában - a veronai és a szegedi egyetem közös vállalkozásában - megjelent facsimile kiadása is, amelyet komoly tanulmánykötettel kísértek. ${ }^{1}$ Összefoglalók születtek a kódex nyelvészeti problémáiról, befejezetlen miniatúradíszítéséről, a magyarországi középkori Dante-recepcióról, a késő középkori magyar könyvkultúráról általában és persze különösen a kódex provenienciájáról. Utóbbinak nem kicsiny a tétje, hisz azt kellene kideríteni, mikor és hogyan juthatott ide; már a 14. század végén vagy csak a 15 . században került Magyarországra? A problémát az okozza, hogy eddig semmiféle magyar vonatkozást nem sikerült benne kimutatnunk. II. Abdülhamid szultán ajándékaként jutott hozzánk 1877-ben, amidőn a szultán úgy döntött, hogy Mátyás király valamennyi könyvét visszaadja a magyaroknak. ${ }^{2}$

A Corvina-könyvtár Budán maradt köteteinek és a Konstantinápolyba hurcolt kódexzsákmánynak hosszú a története, amit e rövid közleményben nem érdemes újra elmondani. 1862-ben háromtagú tudós (utazó)társaság indult Isztambulba, hogy - más célok mellett - felderítsék a Corvina maradványait. Kubinyi Ágoston, Ipolyi Arnold és Henszlmann Imre nagy nehezen elérték, hogy bebocsássák őket a szerájba, és ott két alkalommal is módjuk nyílt több tucat kódex áttanulmányozására. Felfedezésük mérföldkő volt a Corvina kutatásának történetében, mert bebizonyosodott, hogy a királyi könyvtár egy részét csakugyan elhurcolták a törökök Konstantinápolyba. ${ }^{3}$ Ennek lett a következménye, hogy előbb - 1869-ben - Abdülaziz szultán négy kódexet ajándékozott Ferenc Józsefnek mint magyar királynak, majd 1877-ben II. Abdülhamid szultán további harmincöt kódexet adományozott a magyar ifjúságnak. Utóbbiak között volt a Dante-kódex is.

A csak a Corvinára koncentráló kutatás persze rögtön kirostálta a Dantét Mátyás király könyvei közül. Csontosi János tudományos víziójába nem illeszkedett, és csakugyan nincs - nem volt - benne a király címere. ${ }^{4}$ Kihullottak onnét az osztályozás során szép számmal érdekes latin kódexek, egyebek között egy Vitruvius-kézirat is. ${ }^{5}$ Ábel Jenőt, a klasszikus filológust szinte csak az antik auktorok korrekt szövegei (és a kéziratok stemmái) érdekelték, azok kéziratai pedig - a könyvtár relatíve késői gyüjtemény lévén - legfeljebb középszerü másolatoknak bizonyultak. Abel rettentő erudícióval és nagy lendülettel ment neki a latin kéziratoknak, és a Dante-kódexet meg sem említette. ${ }^{6}$ Azóta kicsit változtak a tudomány szempontjai, még a „másodrendü", sőt a félresöpört latin kódexek is felértékelődtek kissé. ${ }^{7}$ A helyzet lassan megérik arra, hogy az Egyetemi Könyvtár „törökországi” kódexei ügyében perújrafelvételt kezdeményezzünk. ${ }^{8}$

A Dante-kódex provenienciájának kérdését régóta igyekezett megoldani a magyar tudomány, de utóbb már nem törekedett a kódex kizárására a királyi könyvtárból. Még a szigorú Balogh Jolán is úgy tekintett rá, mint feltételezett corvinára. ${ }^{9} \mathrm{Az}$ Emo család egyik tagja, Giovanni Emo Budán élt 1463 és 1470 között, tőle kerülhetett a kötet Mátyáshoz - vélekedett ő is. A címert egyébként Berkovits Ilona azonosította az Emo családéval még 1928-ban. ${ }^{10}$ A kéziratot Csapodi Csaba is felvette a Corvina-repertóriumba mint kétséges corvinát. ${ }^{11}$ Nem ártana azonban végre valami konkrét bizonyíték, amivel legalább a magyarországi elszármazást igazolni lehetne. 


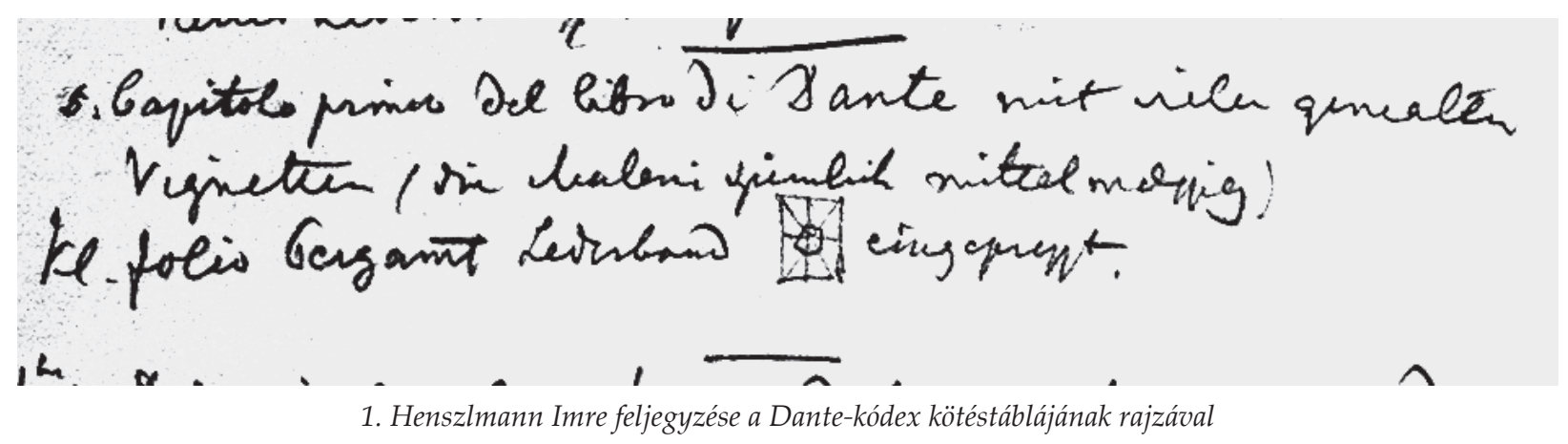

Az első négy corvinát eredeti állapotában adta vissza a szultán. A második harmincötöt azonban előbb újraköttették, és félholddal ékesített, aranyozott, modern bőrkötésben juttatták vissza, mindegyikben aranybetűkkel örökítve meg a szultáni adományozás tényét. Sajnálatos módon ezek a kötetek erősen átnedvesedve érkeztek vissza, s a gombafertőzés később óriási károkat okozott bennük. ${ }^{12}$ A Dante-kódexben különösen. A magyar küldöttség 1862-ben ezeket is eredeti, épebb állapotukban tanulmányozhatta, s az ő hézagos leírásaikból tudtuk meg, hogyan is néztek ki akkoriban. Ipolyi Arnold nyomtatott beszámolója volt a forrásunk hosszú ideig, ezeket egészítette ki Emődi András szerencsés találatával, amikor közölte Ipolyinak a helyszínen készült eredeti feljegyzéseit a nagyváradi Egyházmegyei Levéltárból. ${ }^{13}$ Ezekből a hevenyészett rajzokból ismerjük ma a hajdani, elveszett csatok formáját, a textilborítások színét. Henszlmann feljegyzéseit eddig nem láttuk, azt sem tudtuk, léteztek-e. A tudós múvészettörténész hagyatékának most folyó feltárása során azonban ezek közül is előkerült néhány lapnyi. ${ }^{14}$ Feldolgozásuk folyamatban van, de mivel lényeges újdonságot nem tartalmaznak, előzetesen csak annyit mondhatunk, hogy leginkább a corvinakutatás összképét fogják gazdagítani.

Egyetlen izgalmas kivétel van köztük, a Dantekódex. Henszlmann-nak erről két feljegyzése maradt fenn, egyik tollal és egy másik, ceruzával írott.

„5. [föléje szúrva: XIV] Capitolo primo del libro di Dante mit vielen gemalten vig I netten aus dem Inferno. Die Vignetten malerei ziemlich roh. I kl folii pgmt Lederband

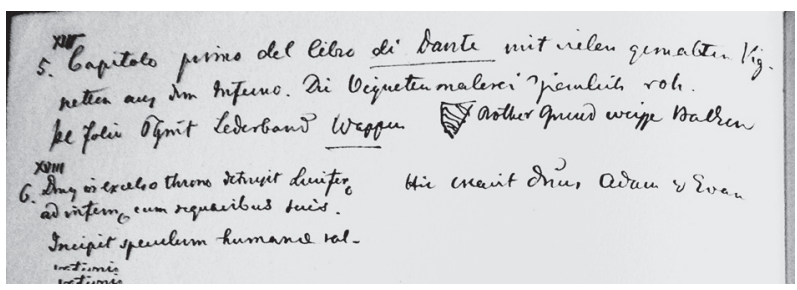

2. Henszlmann Imre feljegyzése a Dante-kódexben található címer rajzával
Wappen [a címerpajzs ábrája] Rother Grund weisse Balken."

„5. Capitolo primo del libro di Dante mit vielen gemalten | Vignetten (die Malerei ziemlich mittelmassig) |

Kl. folio pergamt Lederband [a kötéstábla ábrája] eingepresst."

Csak a ceruzás - itt a második helyen közölt - feljegyzés tartalmazza a kötés igen vázlatos rajzocskáját, a tollal írott csak a címert ábrázolta. Gyakorlatilag hiteles rajz, ha hevenyészett is. Nincs okunk kételkedni abban, hogy a bőrkötésen is ne a rajzolat lényegét ragadta volna meg Henszlmann. A kompozíció igen jellegzetes, centrális típusú. Az álló téglalap alakú lap közepén kisebb kör látható, amelynek közepén a négyszög sarkaiból induló átlók és a négyszög oldalainak közepéről behúzott vonalak metszik egymást. Vagyis - másként fogalmazva - a kör közepéről sugarasan szétfutó nyolc vonal tagolta a kötéstáblát. Ennyi az egész, amit az aprócska rajz mutat.

A kompozíció nem túl gyakori. Jó analógiája azonban éppen az ún. lövöldi corvina háttábláján látható 1488-ból. ${ }^{15}$ Ott hasonlóan futnak szét a vonalak a körből (pontosabban a kör vonaláról), amelynek közepén jókora köldökveret terpeszkedik. A rövidebb oldalak felé azonban még két, fonadékokból összeállított vonal is halad. Az 1477ben Nürnbergben nyomtatott könyv - Raynerius de Pisis Pantheologiája - előtábláját rombuszhálóminta borítja be, a háttábla centrális kompozíciója azonban - a gótikus bélyegzők használata ellenére - reneszánsz ízü. ${ }^{16}$ Legalábbis a vele foglalkozó kötéskutatók egységesen ezt állítják. A lövöldi karthauzi kolostor mühelyében sok könyvet köthettek be, ma tizenegyet ismerünk közülük. ${ }^{17}$ Vajon az, amelyet Mátyás király adományozott a szerzeteseknek, akarattal kapott-e reneszánsz stílusjegyeket idéző kötést? - ezt talán nem szabad feltételezni. A kötés viszont pontosan datált és lokalizált.

A Dante-kódexet ehhez igen hasonló bőrkötés borította; bár ennél többet nem tudunk róla, a kötéstáblát a 15. század végére lehet datálni. Maga a 
kódex 1330-1340 között készülhetett, vagyis kötése jóval későbbi volt. Ha valóban Budáról - vagy akár Magyarországról - került Konstantinápolyba, akkor ez a kötés készülhetett itt is. Félreértés ne essék: egyáltalán nem állítom, hogy a Dante-kódexet Lövöldön kötötték. Erről nincs szó. De késő középkori bőrkötése készülhetett Magyarországon: a centrális kompozíciót itt is alkalmazták. Vékony szál, de erősíti - mert nem gyengíti - a magyarországi provenienciát.

A tágabb körü tanulság pedig az, hogy a Konstantinápolyból 1877-ben Budapestre került 35 kódexet, a kódexek együttesét érdemes volna újra megvizsgálni. A szultáni ajándék talán még a Corvina szempontjából is tartogat számunkra meglepetést.

\section{JEGYZETEK}

1 Dante Alighieri: Commedia. Biblioteca Universitaria di Budapest Codex Italicus 1. I. Riproduzione fotografica. II. Studi e ricerche. A cura di Gian Paolo Marchi e József Pál. Verona 2006.

2 Mikó Árpád: A Corvina-könyvtár történetei. In: Uralkodók és corvinák. Szerk. Karsay Orsolya. Országos Széchényi Könyvtár, Budapest 2002, 128-129; Erödi Béla: Csok jasa! A török küldöttség látogatásának emlékkönyve. Budapest, 1877. Új kiadása: Budapest 2001.

3 Mikó Árpád: A konstantinápolyi corvinák felfedezése. In: Henszlmann Imre (1813-1888). Kiállítás születésének 200. évfordulója alkalmából. Szerk. Bubryák Orsolya. Magyar Tudományos Akadémia, Müvészeti Gyưjtemény, Budapest 2013, 40-42.

4 Csontosi János: A Konstantinápolyból érkezett Corvinák bibliographiai ismertetése. Magyar Könyvszemle II. 1877, 157-218.

5 Hajnóczi Gábor: Bonfini Averulinus-fordítása és a budai Vitruvius-kézirat kérdése, ill. Uô: Vitruvius De architectura című müve a budapesti Egyetemi Könyvtár Cod. Lat. 32. kéziratában. In: Hajnóczi Gábor: Vitruvius öröksége. Tanulmányok a „De architectura” utóéletéről a XV. és XVI. században. Budapest 2002, 77-81., ill. 82-91.

6 Ábel Jenő: Corvincodexek. (Értekezések a Nyelv- és Széptudományok Köréből, VIII. kötet, 1. szám.) Budapest 1879.

7 Kis Farkas Gábor: Adalékok a mítoszok reneszánsz újjászületésének történetéhez. In: Tanulmányok Ritoók Zsigmond hetvenedik születésnapja tiszteletére. Szerk. Hermann István. Budapest 1999, 127-135.

8 A gyüjteményről korrekt áttekintést nyújt Knapp Éva: A „törökországi" kódexek a budapesti Egyetemi Könyvtárban. In: Erôdi Béla: Csok jasa! A török küldöttség látogatásának emlékkönyve. Budapest, 1877. Új kiadása: Budapest 2001, 119-132.

9 Balogh Jolán: A múvészet Mátyás király udvarában. I-II. Budapest 1966, I., 314.

10 Berkovits Ilona: A budapesti Egyetemi Könyvtár Dante-kódexe Budapest 1928; Elena Berkovits: Un codice Dantesco nella Biblioteca della R. Univ. di Budapest. Budapest 1931.
11 Csaba Csapodi: The Corvinian Library. History and Stock. Budapest 1973, 202. (221. sz.)

12 Knapp Éva erre külön kitér, i. m. 131-132.

13 Emődi András: A Corvina-könyvtár kutatásának ismeretlen forrásai a Nagyváradi Egyházmegyei Levéltárban. Magyar Könyvszemle CXXII. 2006, 316-337.

14 Henszlmann Imre kéziratait szülővárosa múzeumára hagyta. A ma a kassai Kelet-Szlovákiai Múzeum kézirattárában (Košice, Východoslovenské muzeum, Rukopisy a pisomností) őrzött anyag átnézése és Henszlmann levelezésének sajtó alá rendezése a K 105005 számú OTKA program támogatásával zajlik. Henszlmann itt idézett feljegyzései a poradove čislo 730. számon találhatók, a dobozon belül különböző helyeken. Nagyon köszönöm Szentesi Editnek, hogy a konstantinápolyi útra vonatkozó anyagot feldolgozásra odaadta nekem.

15 A kötetet Esztergomban őrzik, a Főegyházmegyei Könyvtárban (Inc. I. 1 a-b). (Géza Sajó - Erzsébet Soltész: Catalogus incunabulorum Hungariae quae in bibliothecis publicis Hungariae asservantur. Budapest 1970, 2897. sz.; Csapodi Csaba i. m., 566. sz.) B. Koroknay Eva: A lövöldi karthauzi kolostor kötései. Esztergom Évlapjai 1960, 25-34., 214223; Sz. Koroknay Éva: Magyar reneszánsz könyvkötő mühelyek. 1470-1520. Budapest 1966-1967, 29-30 (8. sz.) I. tábla

16 Rozsondai Marianne: Magyarországi gótikus és reneszánsz bőrkötések. (Vázlat, a feladatok kijelölése.) Ars Hungarica XVII. 1989, 63-64; Rozsondai Marianne: Magyar gótikus és reneszánsz könyvkötések. In: Pannonia regia. Müvészet a Dunántúlon 1000-1541. Szerk. Mikó Árpád Takács Imre. Magyar Nemzeti Galéria, Budapest 1994, 451; Rozsondai Marianne: A könyvkötés müvészetének rövid története. Országos Széchényi Könyvtár, Budapest 2004², 17. - Köszönöm Rozsondai Marianne-nak, hogy a dolgozatot elolvasta s publikálására biztatott.

17 Muckenhaupt Erzsébet: Lövöldi kötés a csíksomlyói ferences könyvtárban. In: Emlékkönyv Jakó Zsigmond nyolcvanadik születésnapjára. Szerk. Kovács András - Sipos Gábor - Tonk Sándor. Kolozsvár 1996, 402-408; Muckenhaupt Erzsébet: A csíksomlyói ferences könyvtár kincsei. Budapest-Kolozsvár 1999, 67-68. 
On the original binding of the Dante Manuscript (Cod. Ital. 1) kept in the University Library. An unpublished note by Imre Henszlmann. The Dante Manuscript, which currently is to be found in the possession of the Library of the Eötvös Loránd University in Budapest with the label Cod. Ital. 1. (La Divina Commedia) has been brought there in 1877, when Sultan II. Abdulhamid sent back 35 ancient manuscripts to Hungary. All of them were in uniformly bound in leather, in the style of the Turkish trend of the era. These codexes have been studied in 1862 by Ipolyi Arnold and Henszlmann Imre in Istambul, in their original binding. We know many of them from the notes - taken in situ and published only in 2006 - of Ipolyi, but the original leather binding of the Dante-codex is known to us only from the sketch of Henszlmann published here for the first time.

MIKÓ Árpád, MTA Bölcsészettudományi Kutatóközpont Müvészettörténeti Intézet / Research Centre for the Humanities Hungarian Academy of Sciences, Institute of Art History, miko.arpad@gmail.com

Kulcsszavak: Dante Alighieri, Divina Commedia, illuminált kódex, bőrkötés, II. Abdülhamid szultán, Isztambul, Henszlmann Imre / Keywords: Dante Alighieri, Divina Commedia, illuminated manuscript, leather binding, Sultan II. Abdulhamid, Istambul, Imre Henszlmann 